\title{
The endovascular journey
}

Anthony J. Furlan, MD

Correspondence \& reprint requests to Dr. Furlan: anthony.furlan@uhhospitals.org

Neurology ${ }^{\circledR}$ 2012;79 (Suppl 1):S205-S206
The Society of Vascular \& Interventional Neurology (SVIN) Roundtable on Endovascular Therapy for Acute Ischemic Stroke provides an excellent roadmap not only for how far we have come but also for the long trip remaining on the road to successful acute stroke intervention. The final destination is comprehensive stroke systems integration-health care delivery systems providing rapid access to integrated, innovative, and individualized stroke care from prevention through rehabilitation (daresay "restoration"). The emphasis of the roundtable is on technology, and information technology will be used to improve lifestyle education beginning in early childhood. In Cleveland we have launched the Healthy Brains Healthy Communities initiative in conjunction with the public school system. Fewer patients will need reperfusion therapy if there are fewer strokes.

But strokes will still occur, and patients must still get to the hospital. Fortunately, it is getting easier to get to the right hospital. Soon more than $80 \%$ of the US population will be within 15 minutes of a certified stroke center and will have access to the latest diagnostic technologies and therapeutic interventions. Stimulated by the introduction of IV tissue plasminogen activator ( $\mathrm{tPA}$ ), there are now more than 700 Joint Commission-certified primary stroke centers. Soon, comprehensive stroke centers will anchor stroke systems that include primary stroke centers and rural hospitals linked through telestroke communications. This represents an amazing paradigm shift in our approach to acute stroke, considering the only "therapy" available when I was a stroke fellow was IV heparin, often started 2 or 3 days after stroke onset.

But there remain voices of caution, if not nihilism, because the new stroke diagnostics and therapeutics are expensive and "unproven." Some have argued the system will not really change until we have "proof" of efficacy and new technologies are shown to be cost-effective. Indeed, comparative effectiveness pressure is certain to increase in the looming era of health care cost control and outcomes assessment. We will not be allowed to use endless catheters or to take unlimited pictures in every acute stroke patient coming through the door (by helicopter, no less). Therefore, the interventional stroke community's biggest challenge is not to design catheters but to refine patient selection criteria so that the right stroke patient gets the right therapy at the right time.

Keeping in mind that there are approximately 800,000 new strokes each year, the number of potential candidates for interventional ischemic stroke therapy in the United States has been estimated to be between 10,000 and 40,000 per year. ${ }^{1-3}$ There has been only 1 completed randomized, controlled trial (RCT) of intra-arterial thrombolysis, Prolyse in Acute Cerebral Thromboembolism (PROACT) II, and the need for and feasibility of another intraarterial RCT has been hotly debated. Some have argued that more trials are neither necessary nor feasible, whereas others would put a moratorium on intra-arterial stroke therapy outside of an RCT.4-5 To be sure, technology tends to leap ahead of its wise application, as witnessed by the ever-evolving penumbra story and the plethora of reimbursed "approved but unproven" thrombectomy devices on the market. We will need to take small steps first. Stroke heterogeneity ${ }^{6}$ remains the central challenge of ischemic stroke trial design; we cannot design trials based mainly on marketing considerations. New trial methodologies and new imaging technologies are required in order to build a physiologic approach to acute stroke therapy, to reduce sample size, and to optimize the likelihood of demonstrating efficacy. If the SVIN roundtable provides a roadmap to this goal, then perhaps the Stroke Academic Industry Roundtable (STAIR) provides the global positioning system for our destination. ${ }^{7}$ Regardless, as we refine our directions, the stroke journey continues; time is brain, but we must avoid shortcuts and dead ends.

\section{AUTHOR CONTRIBUTIONS}

A.J.F. participated in drafting/revising the manuscript and review of symposium presentations. 


\section{DISCLOSURE}

Dr. Furlan served as a consultant for NMT Medical, Boston. Go to Neurology.org for full disclosures.

Received July 10, 2011. Accepted in final form December 29, 2011.

\section{REFERENCES}

1. Hirsch JA, Yoo AJ, Nogueira RG, et al. Case volumes of intra-arterial and intravenous treatment of ischemic stroke in the US. J Neurointerv Surg 2009;1:27-31.

2. Cloft HJ, Rabinstein A, Lanzino G, et al. Intra-arterial stroke therapy: an assessment of demand and available work force. AJNR Am J Neuroradiol 2009;30:453-458.

3. Suzuki S, Saver JL, Scott P, et al. Access to intra-arterial therapies for acute ischemic stroke: an analysis of the US population. AJNR Am J Neuroradiol 2004;25:18021806.

4. Furlan AJ. Clot retrieval for stroke should be restricted to clinical trials: no. Stroke 2010;41:194-199.

5. Schellinger PD, Hacke W. Recanalization devices should be restricted to clinical trials: pro (kind of). Stroke 2010; 41:191-193.

6. Muir KW. Heterogeneity of stroke pathophysiology and neuroprotective clinical trial design. Stroke 2002;33: 1545-1550.

7. Saver JL, Albers GW, Dunn B, Johnston KC, Fisher M, for the STAIR VI Consortium. Stroke Therapy Academic Industry Roundtable (STAIR) recommendations for extended window acute stroke therapy trials. Stroke 2009; 40:2594. 


\section{Neurology}

The endovascular journey

Anthony J. Furlan

Neurology 2012;79;S205-S206

DOI 10.1212/WNL.0b013e318269594b

This information is current as of September 24, 2012

\section{Updated Information \&} Services

References

Subspecialty Collections

Permissions \& Licensing

Reprints including high resolution figures, can be found at: http://n.neurology.org/content/79/13_Supplement_1/S205.full

This article cites 6 articles, 5 of which you can access for free at: http://n.neurology.org/content/79/13_Supplement_1/S205.full\#ref-list1

This article, along with others on similar topics, appears in the following collection(s):

\section{All Cerebrovascular disease/Stroke}

http://n.neurology.org/cgi/collection/all_cerebrovascular_disease_strok e

\section{All Clinical trials}

http://n.neurology.org/cgi/collection/all_clinical_trials

Information about reproducing this article in parts (figures,tables) or in its entirety can be found online at:

http://www.neurology.org/about/about_the_journal\#permissions

Information about ordering reprints can be found online:

http://n.neurology.org/subscribers/advertise

Neurology ${ }^{\circledR}$ is the official journal of the American Academy of Neurology. Published continuously since 1951, it is now a weekly with 48 issues per year. Copyright Copyright (? 2012 by AAN Enterprises, Inc.. All rights reserved. Print ISSN: 0028-3878. Online ISSN: 1526-632X.

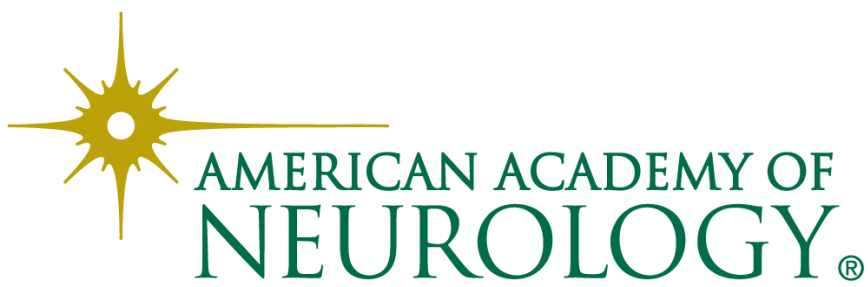

